\title{
Amelia Bloomer, A Biography
}

\author{
Part I \\ The Lily of Seneca Falls
}

\section{LOUISE NouN}

AmELIA BloOMER'S posthumous induction into the Iowa Women's Hall of Fame in 1975 gave her an overdue honor from the state which was her home for almost forty years. A native of New York State, Bloomer settled in Council Bluffs in 1855. As an earnest advocate of woman's rights, she brought her advanced views to lowa long before they were popular or even acceptable. Ridiculed for her ideas before the Civil War, villified in the postwar era, and finally ostracized from the Iowa woman's rights movement, Bloomer fell from the limelight. Only now, with the new interest and scholarship in the histories of the woman's rights and temperance movements, is it possible for Amelia Bloomer to emerge from that obscurity.

Obscurity did not mean complete anonymity for Amelia Bloomer, because her name became permanently associated with the articles of clothing that bore it. "Bloomers" meant a picturesque reform dress worn in the mid-nineteenth century, voluminous gymnasium pants for young women of the 1920s, and finally just plain underpants. Amelia Bloomer, however, was far from a single-minded advocate of dress reform. Her newspaper, the Lily, published from 1849 until her move to

Cheryl Schmidt, "Manuscript Collections: The Papers of Amelia Jenks Bloomer and Dexter Bloomer," Annals of Iowa 45 (Fall 1979), 135-146 provides some information and a bibliography of works concerning Amelia Bloomer. It does not mention, however, that the University of Iowa Libraries hold microfilm of the Lily, and that to my knowledge, there is no complete microfilm of the entire Lily. 
Iowa in 1855, was the first publication in the United States to espouse the cause of woman's rights. Conservative by temperament and upbringing, she joined the woman's rights movement in the 1850 s because she hoped women could use the ballot to outlaw the sale and consumption of alcoholic beverages. From this reluctant commitment to one means to an end, she gradually developed an ardent advocacy of the woman's cause for its own sake, even in the face of the most exasperating discouragements.

Amelia Jenks was born in Homer, Cortlandt County, in western New York State, on May 27, 1818. She was the daughter of Ananias and Lucy Webb Jenks who had moved from Rhode Island to western New York soon after their marriage in 1806. Amelia's father was a clothmaker who, according to Amelia, was at one time well-to-do but later became impoverished. Her mother, the child of devout New England Puritans, was a faithful member of the Presbyterian church. Amelia, her two brothers, and her three sisters received a strict religious upbringing and observed the Sabbath from sundown on Saturday until sunset the following day. The Jenks family moved from Homer when Amelia was six and settled successively in nearby Wayne and Seneca counties. Amelia's childhood memories were happy ones. ${ }^{1}$

Although Amelia must have been oblivious to them as a child, the fires of religious revivalism known as the Second Great Awakening swept western New York State in the early nineteenth century and gave it the name "Burned Over District." The clergy exhorted audiences to seek salvation through morally responsible contributions to their communities, and encouraged women, for the first time, to participate vocally in the revival meetings by praying or reciting religious experiences. This revivalism, which subsided about 1835, helped create the atmosphere in which moral reform movements such as temperance, abolitionism, and woman's rights flourished prior to the Civil War. ${ }^{2}$

1. D[exter] C. Bloomer, ed., Life and Writings of Amelia Bloomer (Boston, 1895), 7-10; "By Gone Days," Lily, June 1849.

2. Alice B. Rossi, ed., The Feminist Papers: From Adams to DeBeauvoir (New York, 1973), 252-257. For discussion of religious revivalism and the woman's movement, see Leslie Epstein, The Politics of Domesticity: Woman, Evangelism, and Temperance in Nineteenth Century America (Middletown, Conn., 1981). 
Amelia received her education, as was customary for most girls of her time, in a country school where she learned the basic elements of reading, writing, and arithmetic. Because her parents were poor, she had to earn her own living from an early age. She worked at two of the occupations most accessible to unmarried young women: teacher and governess. Her teaching career was limited to one term in a country school near the village of Clyde. When she was seventeen, she spent some time with her married sister, Elvira, in Waterloo, a village in Seneca County, and in 1837 took a position as governess to the family of Oren Chamberlain, a wealthy farmer who lived near Waterloo. She looked after the family's three daughters who ranged in age from three to twelve. The position gave her time to do the independent reading that she enjoyed. ${ }^{3}$

A frequent visitor at the Chamberlain home was Oren Chamberlain's nephew, Dexter Bloomer. Dexter soon became enamored of Amelia but she was reluctant to marry him because his manners seemed uncouth and she disapproved of his use of alcohol, moderate though it was. Dexter, two years older than Amelia and of Quaker background, was born on July 4, 1816, in Cayuga County, New York. His father, John Bloomer, was a native of Westchester County. His mother, Tamma Chamberlain, was born in Massachusetts. When Dexter was seven years old his parents moved to a log house on a partially cleared farm in Cortlandt County where for five years they tried unsuccessfully to earn a living. In 1828 they moved to a farm half-way between Seneca Falls and Waterloo, near Tamma's Chamberlain relatives who were prosperous farmers. Dexter attended nearby public or private schools as often as possible. He liked to read and took an early interest in politics. After his mother died in 1831 Dexter lived most of the time with his Chamberlain relatives until he began teaching school at eighteen. Two years later he caught the western fever, went as far as Detroit by canal boat and lake steamer, but returned home unable to find work. The following year he settled in Seneca Falls and began to study law. In 1839, with his friend, Isaac Fuller, he purchased the biweekly Seneca County Courier, a Whig newspaper, which he edited intermittently for

3. D. C. Bloomer, Life, 10-11. 


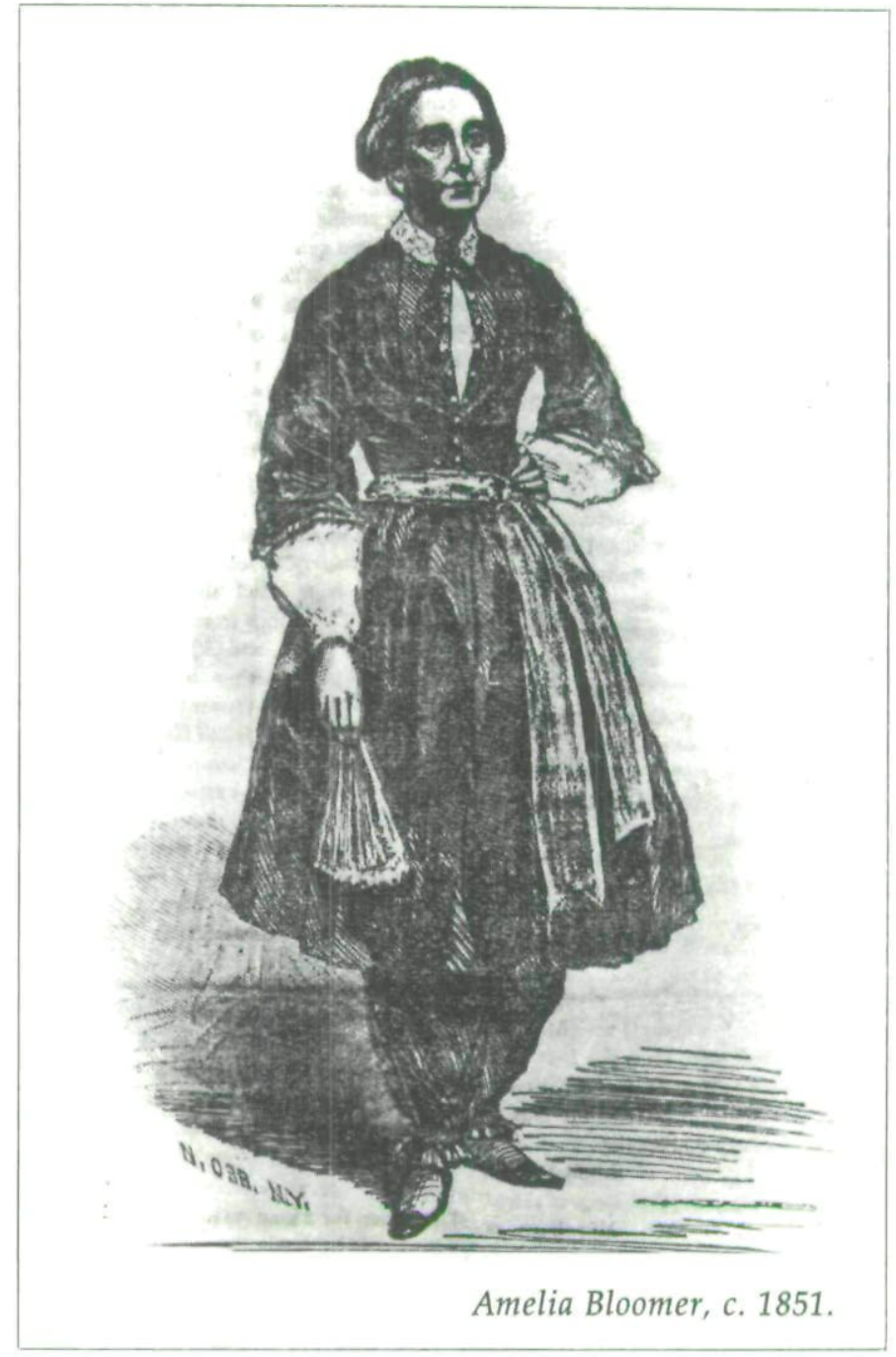

the next fifteen years. He also became clerk of Seneca Falls, a village of three thousand, and was appointed clerk for the canal superintendent as well. ${ }^{4}$

Amelia recalled her courtship and marriage in a story she published in an early issue of the Lily. With fictitious names she related how she came to appreciate Dexter's finer qualities and convinced him to give up alcohol. She was not pleased

4. Ibid., 12-13; "Woman's Influence," Lily, September 1849; Dexter Bloomer, "Some Events of My Life," Dexter Bloomer journal, Iowa State Historical Department, Des Moines (hereafter referred to as ISHD-DM). 
with Dexter at first; she found him annoyingly awkward, reserved in company, and unpolished in manners. She soon came to realize, however, that his rough exterior overlay a warm heart and a good intellect. Amelia concluded that he was a rough diamond who only needed polishing in order to shine. After a two-year courtship, the couple married in Waterloo on April 15, 1840, in the home of Amelia's sister, Elvira. Although Amelia had not yet developed a strong feminist consciousness, she always appreciated the progressiveness of the Presbyterian minister who performed the marriage ceremony: he did not ask her to promise to obey her husband. ${ }^{5}$

Contrary to prevailing custom, Amelia decided not to serve wine at her wedding. She had heard about and seen the evils of intemperance and had known young men who had started on their downward paths by taking their first drinks at weddings or parties. She could neither serve such a poisonous refreshment to her guests nor offer her husband that fatal cup which might turn him into a demon and embitter all her days. She made this decision without consulting her fiance, according to her own conscience and without concern for what others might say. ${ }^{6}$

In later life Bloomer recalled that when she was young drinking was a common practice. Decanters and glasses on the sideboard were necessary to every household and it was impolite not to offer a drink to the hired man or to guests. A visiting minister would expect a hot toddy before breakfast. The use of alcohol was so prevalent that when the first temperance wave swept the country there was discussion about whether or not laborers would be willing to harvest the grain without their customary allowances of whiskey. There had been little or no regulation of the liquor business and widespread consumption of hard liquor had existed in America since before the revolution. ${ }^{7}$

Bloomer, as an ardent foe of liquor, was attuned to the growing reform spirit of her times. From the 1820s through the

5. D. C. Bloomer, Life, 13; "Woman's Influence."

6. "Woman's Influence."

7. Amelia Bloomer, temperance lecture, no date, Seneca Falls Historical Society, Seneca Falls, New York; Ida Husted Harper, The Life and Work of Susan B. Anthony (Indianapolis, 1899), 1:61. 


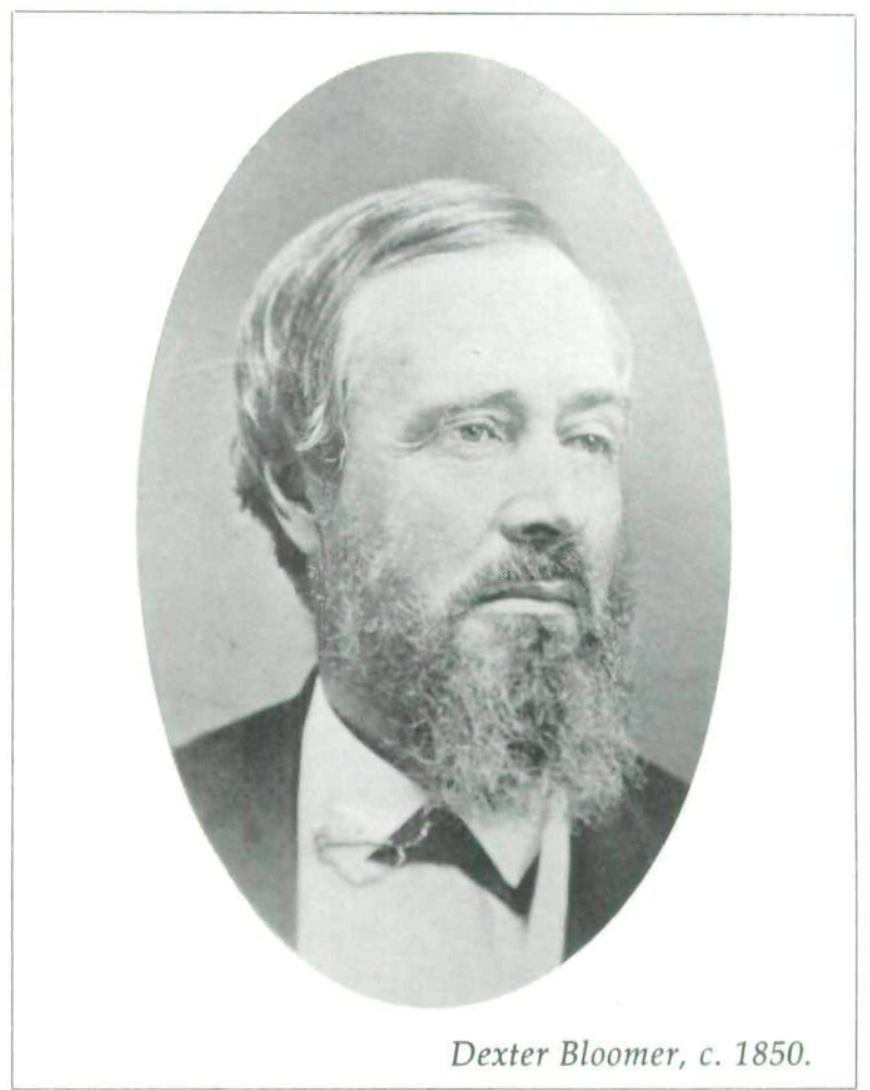

1840 s, a temperance crusade swept the country and upper New York State was its stronghold. In the early days of the movement the term "temperance" related to moderate drinking but it soon became synonymous with prohibition. Initially the clergy lead the movement along with their male parishioners. Most people assumed that drinking was a male problem, even though there were many female alcoholics. Woman's particular job was to exert moral influence, stop men from drinking, and keep liquor out of the home. Amelia Bloomer considered it her duty to persuade her husband to give up the use of alcohol. ${ }^{8}$

She was dismayed to see wine flow freely at a welcoming party which Dexter's friends in Seneca Falls gave the day after

8. Standard Encyclopedia of the Alcohol Problem (Westerille, Ohio, 1925), 5:1941-1942; "Can Woman Fall So Low?" Lily, March 1849; "Women and Liquor," Lily, April 1850; D. C. Bloomer, Life, 166. 
her wedding. This gathering took place in Isaac Fuller's home where the Bloomers temporarily resided. During the evening Dexter drank numerous toasts with his friends while Amelia politely but firmly refused every drink offered. She sensed that her behavior mortified her husband, but he said nothing to her about it. At last he asked her to drink just one glass with him. She refused. "I felt it rather keenly at the time," Dexter wrote in his old age, "but she was certainly right."

In early October 1840 the Bloomers moved into a home of their own on East Bayard Street. Dexter soon disturbed its tranquility by expressing a desire to keep wine and liquor for entertainment purposes. Amelia was indignant at the mere suggestion. Dexter argued that all of their friends served alcoholic beverages and that they should also. Amelia retorted that if their friends could not visit without receiving alcoholic poison, then they should stay away. Her will prevailed, but Dexter continued to drink with his business associates. He feared abstention would be unsociable, especially since he felt no risk of alcoholism. ${ }^{10}$

Dexter fulfilled his wife's fondest dream by giving up intoxicating drink sometime during the fall or winter of 1841-42 when the Washingtonian movement arrived in Seneca Falls. This movement had originated in Baltimore in 1840 when six drunkards took a pledge never to touch liquor again. They organized themselves into a Washington Society in honor of the country's first president and invited others to join. Washingtonians traveled the countryside with dramatic recitations of their falls to the gutter and their reformations, given in meetings which resembled, in spirit if not in content, traditional religious revivals. They exhorted men in the audience to come forward and sign the total-abstinence pledge. The Washingtonians were loosely organized and short-lived, but they broadened the base of and infused new life into the mainstream temperance movement. They also paved the way for the first women's temperance organizations. ${ }^{11}$

9. D. C. Bloomer, Life, 15-16; "Woman's Influence," Lily," September 1849; Dexter Bloomer, "Some Events."

10. D. C. Bloomer, Life, 18; "Woman's Influence."

11. D. C. Bloomer, Life, 20-21, 25-26; Alice Felt Tyler, Freedom's Ferment: Phases of American Social History from the Colonial Period to the Outbreak of the Civil War (New York, 1944), 338-346. 
When two of the founding Washingtonians arrived in Seneca Falls, they aroused great curiosity. Former alcoholics rarely spoke of their curse in public. Amelia Bloomer urged Dexter to hear them, but he hesitated. He said he was no drunkard and would not have his name on the same roll with reformed drunkards. Nevertheless, he attended the Washingtonian meetings and their emotional appeal captured his enthusiasm. Along with some of the village's most prominent citizens, he signed the total-abstinence pledge. At last Bloomer felt her husband was safe. She was sure his reformation was permanent and her judgment was correct. For the rest of his life Dexter was committed to the temperance cause. Amelia looked back to the day he signed the pledge as the happiest of her life. Twenty years later she still thrilled at the memory of the Washingtonian days. In a letter to the editor of the Seneca County Courier she recalled a temperance meeting in the orchard of Ansel Bascom, a Seneca Falls lawyer and reform leader, at which the two reformed drunkards appeared. They warned of the evil of drink and urged enrollment in the great temperance army. After twenty years Bloomer could still envision men in the audience coming forward, one by one, to sign the pledge. Temperance was truly popular then, Bloomer recalled. ${ }^{12}$

The Washingtonian movement inspired a campaign to rid Seneca Falls of the liquor evil and in the spring elections of 1842 a large majority voted for an anti-liquor ticket. Thus the village banished the sale of alcohol. Reform enthusiasm spilled over into the town's Fourth-of-July celebration when a temperance procession of some four hundred people marched to the accompaniment of music, cannon fire, and bell ringing. The parade terminated at Bascom's orchard where Dexter Bloomer delivered an eloquent address. In closing he proclaimed the motto "liberty and temperance now and forever, one and inseparable." The marchers feasted at bower-shaded tables and offered many fine toasts to the Washingtonians and to "the ladies, ever the champions of a good cause." 13

The ladies of Seneca Falls deserved this tribute. Soon after

12. "Woman's Influence"; Amelia Bloomer, "Twenty Years Ago," 1 May 1862, Seneca Falls Historical Society.

13. Harrison Chamberlain, "The Seneca Falls Press," Papers Read Before the Seneca Falls Historical Society (Seneca Falls, 1905), 4. 
the Washingtonian movement arrived in Seneca Falls, about two hundred women joined together in a Martha Washington Society to support the men's cause. This was the first woman's temperance society in the community and was similar to other groups which sprang up throughout western New York State at this time. The Martha Washingtons were active in the successful anti-license campaign of 1842 . After this victory they carried the temperance message directly into homes through personal visits and the distribution of leaflets which lamented the evils of drink. They also made a banner for the men's society which they decorated with a local artist's rendition of George Washington. A committee meeting in Eliza Bascom's kitchen sewed the stars and stripes onto the banner. Since it was socially improper for women to speak in public, Eliza's husband Ansel presented the banner to the men's society in a ceremony in Bascom's orchard. The president of the Martha Washingtons, Eliza, remained modestly on the sidelines. ${ }^{14}$

Amelia Bloomer, who described herself at the time as a "shrinking, bashful woman, just entering upon a new life with strangers," joined in the Martha Washingtons' activities with earnest zeal. She served on committees and wrote articles for the Water Bucket, a temperance paper which began publication in Seneca Falls in February 1842. John Jay Davis, a reformed drunkard, was the editor. Bloomer's articles were her first efforts for the public press and in accordance with prevailing custom-which demanded that women have no public presenceshe used various pseudonyms when signing her work. She signed an article-which told women not to have alcohol in the home even for cooking purposes-"Gloriana," and another, signed "Eugene," exhorted men to aid the weak by encouraging reformed drunkards to go to the Temperance Hall instead of reverting to their old haunts, the grogshop and the gutter. Alas, John Jay Davis himself succumbed to temptation and once again became a drunkard. The Water Bucket expired with Davis's downfall soon after the Fourth-of-July temperance celebration. After the Water Bucket's demise Bloomer continued

14. Lily, January 1849; Epstein, Politics of Domesticity, 91-92; Chamberlain, "Seneca Falls Press," 5; Mary Bull, "Woman's Rights and Other 'Reforms' in Seneca Falls," New York History, (January 1965), 328-336 (originally published in Good Companion, 5:10, Springfield, Mass., 1880). 
to write temperance pieces for the Free Soil Union, for the Temperance Star of Rochester, New York, and for the Seneca County Courier. ${ }^{15}$

The Washingtonian movement was short-lived, and like the editor of the Water Bucket, many of the men who signed the pledge soon returned to their old ways. The voters threw the reform ticket out of office at the next election and liquor flowed as usual in the community. The women tried to stem this alcoholic tide, but their efforts were in vain and the Martha Washington Society soon ceased to exist. In 1843, however, Bloomer found a new outlet for her energy when she and Dexter joined the Episcopal church in Seneca Falls. She participated in local women's religious activities and remained a devout Episcopalian for the rest of her life. ${ }^{16}$

Amelia Bloomer, in 1843, was twenty-five years old. She was short with a petite figure, dark blue eyes, and auburn hair. Her contemporaries considered her rather plain but noted her pleasant countenance, genial disposition, and winning smile. Her husband was tall and thin and when they walked down the street together the difference in their statures attracted attention. She was ill at ease in new social situations, especially when meeting people with more wealth and sophistication than she had known. Yet she was earnestly committed to any cause with which she associated. Although her timidity often made decisionmaking difficult for her, once she made up her mind, she followed the chosen course with single-minded devotion. A perceptive phrenological analysis of Bloomer's character in 1853 noted

She has two classes of faculties existing in nearly equal power.... One impels her forward to do and dare everything that she thinks is right; the other leads her to shrink from rough encounter with the world, to dread criticism and censure, and yield to the blasts of reproof; the one tells her she can do if she will, the

15. Amelia Bloomer, "Twenty Years Ago"; D. C. Bloomer, Life, 21-25; Chamberlain, "Seneca Falls Press," 5; Amelia Bloomer to Elizabeth Boynton Harbert, Chicago Inter-Ocean, 12 March 1881, Elizabeth Boynton Harbert scrapbook, 3:68, Elizabeth and Arthur Schlesinger Library, Radcliffe College.

16. Chamberlain, "Seneca Falls Press"; D. C. Bloomer, Life, 26-27. 
other that she cannot, and effort is useless. And as these mental conditions alternately gain the mastery, her character is differently estimated. By one she is considered forward, heroic and eager to lead; by another sensitive, and exceedingly modest. ${ }^{17}$

Bloomer also never enjoyed good health. She had frequent headaches and a stomach ailment for which she often sought treatment in one of the many hydropathic institutions which dotted western New York State in the 1840s. One cannot help but speculate that Bloomer's headaches may have resulted, at least in part, from her intense disposition and inner conflicts about facing new or controversial situations. Fortunately she had a loving husband who encouraged her to write and who supported her reform activities. Dexter was a quiet, industrious young man whom the Bascom's daughter, Mary Bull, described as "not easy to know well but much respected by those who did know him." He was politically active and for his support of the Whig party Millard Fillmore appointed him postmaster of Seneca Falls in 1850. Dexter immediately made Amelia his deputy postmaster and she ran the office for him. Bloomer, who was childless, often also cared for children of relatives who lived with her for extended periods. ${ }^{18}$

On the nineteenth and twentieth of July 1848, Amelia Bloomer attended a most unusual meeting in Seneca Falls' Wesleyan Chapel. Elizabeth Cady Stanton of Seneca Falls, Lucretia Mott, a well-known Philadelphia Quaker, and other liberal Quakers from nearby Waterloo had called a convention to discuss woman's rights. The organizers, who were too timid to put their names on the call when the Courier published it, were amazed at the response. Three hundred people attended, forty of them men. Many came out of sympathy for the cause, but many more from sheer curiosity. Amelia Bloomer was among

17. "Character and Biography of Amelia Bloomer," American Phrenological Journal, March 1853, 51; D. C. Bloomer, Life, 13-14, 306.

18. Bull, "Woman's Rights." References to Amelia Bloomer's health occur in D. C. Bloomer, Life, 17, 79, 129, 190. On the postmastership, see Life, 19; Dexter Bloomer, "Some Events"; Theodore Stanton and Harriet Stanton Blatch, eds., Elizabeth Cady Stanton as Revealed in Her Letters, Diary, and Reminiscences (New York, 1922), 1:171. On the Bloomers' adopted children, see D. C. Bloomer, Life, 299-300. In the October 1850 Lily, Amelia Bloomer mentioned that she was caring for "a little prattler." 
the curious. Seneca Falls had grown accustomed to temperance meetings where women gathered quietly to support the men's fight against liquor and to church gatherings where women sewed to earn pennies that would educate young men for the ministry. But this meeting in the Wesleyan Chapel was different; it was a public meeting called by women to promote the cause of women. They were making demands for their own welfare, not someone else's. The changes they wanted would affect daily lives of all men and women. This Seneca Falls meeting was a revolutionary event. ${ }^{19}$

The primary force behind this woman's rights meeting - the first of its kind in the United States-was Elizabeth Cady Stanton, who had moved to Seneca Falls from Boston just a year before. Three years older than Bloomer, plump and scarcely five feet tall, she differed considerably from Bloomer in temperament, education, and background. Unlike Bloomer, who had to earn her own living when still in her teens, Stanton was from a wealthy patrician New York family. Stanton's mother was related to the old Dutch aristocracy in New York; Stanton's father, a prominent attorney and judge, ruled over the Cady mansion in nearby Johnstown. Elizabeth received her education at Emma Willard's pioneering school for women. She was urbane, self-assured, brilliant, witty, and a religious freethinker. She married Henry Stanton, a well-known abolitionist, in 1840 . That year they attended an antislavery convention in London to which Henry was a delegate. There they met Lucretia Mott, who was denied her seat as a delegate because of her sex. Elizabeth Cady Stanton and Mott spent many hours there discussing woman's subordinate place in society. Their friendship and concerns resulted in the Seneca Falls convention eight years later. When living in Boston, Stanton had enjoyed the friendship of the leading abolitionists and liberal thinkers of the day, but her life changed dramatically when she moved to Seneca Falls in 1847. She felt tied to their home on the outskirts of a small town with an increasing number of children and a paucity of intellectual stimulation. To relieve

19. Eleanor Flexner, Century of Struggle: The Woman's Rights Movement in the United States (Cambridge, 1959), 71-79; D. C. Bloomer, Life, 31-33; Rossi, ed., Feminist Papers, 273. 
her boredom she organized a conversation club modeled on the "conversations" of Margaret Fuller, the Boston feminist writer. When Lucretia Mott came to Waterloo in the summer of 1848 to attend a meeting of progressive Friends (Quakers), Stanton enlisted her help in organizing a woman's rights meeting. ${ }^{20}$

Stanton and Bloomer traveled in different social circles and their interests diverged significantly. Stanton was a member of the social elite of Seneca Falls; Bloomer was not. Stanton was a freethinker who disregarded the Sabbath; Bloomer was a devout Episcopalian who attended church twice each Sunday. According to Stanton, Bloomer "stood aloof and laughed at us" at the first woman's rights convention. The two had not met and it seemed unlikely that they would soon have a close relationship. The platform adopted at the Seneca Falls convention was decades ahead of public opinion and Bloomer was not alone in her rejection of its principles, yet it influenced her thinking. The meeting produced a Declaration of Sentiments, based on the wording of the Declaration of Independence, which emphasized that all men and women are created equal. It charged that women had to submit to laws which they had no voice in making and that in marriage husbands controlled their wives' persons and property. Men framed divorce laws and made child custody decisions without regard for women's happiness; monopolized the most profitable jobs and professions; denied women educational opportunities including college; allowed women only subordinate roles in the church; and created a double standard of morals by which the delinquencies of men were deemed of little account but those of women could exclude them from society. The declaration stated that men had endeavored in every way they could to destroy women's confidence in their own powers, lessen their selfrespect, and thus make them submit to dependent lives. ${ }^{21}$

20. Edward T. James, ed., Notable American Women: A Biographical Dictionary (Cambridge, 1975), 3:342-344; see also Lois W. Banner, Elizabeth Cady Stanton: A Radical for Woman's Rights (Boston, 1980); Elisabeth Griffith, In Her Own Right: The Life of Elizabeth Cady Stanton (New York, 1984); Stanton and Blatch, eds., Elizabeth Cady Stanton, 1:125-145; D. C. Bloomer, Life, 131. Lois Banner calls Stanton by the name she preferred herself, "Cady Stanton," which the author also prefers. In keeping with editorial practice, the Annals editors have chosen to use "Stanton."

21. Bull, "Woman's Rights"; Elizabeth Cady Stanton to Susan B. Anthony, 
The Seneca Falls convention also adopted a series of resolutions which recommended remedies for the wrongs women suffered, including the right of female suffrage. This right was the most controversial of the issues discussed at the convention and was adopted only over many objections. Amelia Bloomer, however, could most easily relate to the final resolution adopted: it declared every woman's right to participate in reform activities on an equal basis with men, especially moral and religious reform. It also affirmed women's right to speak in public and to further good causes by writing. One hundred people signed the Declaration of Sentiments and the resolutions, not including Bloomer, but many later retracted their signatures when the meeting aroused a storm of abuse and criticism from relatives, the clergy, and the press. Yet despite this unpopularity, the Seneca Falls convention released latent woman's rights sentiment. A similar convention met in Rochester two weeks later, and the first of a series of annual national woman's rights conventions met in Worchester, Massachusetts, in 1850. The Civil War, however, brought a halt to these meetings. ${ }^{22}$

Although the 1848 Seneca Falls convention did not necessarily convert conservative church-oriented women like Bloomer to the woman's rights cause, it inspired them to other actions. In September 1848 Bloomer helped to organize the Ladies Total Abstinence Benevolent Society of Seneca Falls and was elected its secretary. This was the first woman's temperance society in the community since the Martha Washingtons and, unlike its predecessor, it was not a subservient auxiliary to any men's group. Bloomer was also no longer satisfied with writing anonymous articles for men's publications and thought the Ladies Total Abstinence Society should publish its own temperance paper. After discussing the project with local poet

2 April 1852, in Stanton and Blatch, Elizabeth Cady Stanton, 2:39; Mari Jo Buhle and Paul Buhle, eds., The Concise History of Woman Suffrage: Selections from the Classic Work of Anthony, Gage, and Harper (Urbana, 1978), 89-90; Elizabeth Cady Stanton, Susan B. Anthony, and Matilda J. Gage, eds., History of Woman Suffrage (Rochester, 1881), 1:70-71.

22. Stanton et al, eds., History, 1:72; Banner, Elizabeth Cady Stanton, 42; Stanton and Blatch, Elizabeth Cady Stanton, 1:146-148; Flexner, Century of Struggle, 80-81. 


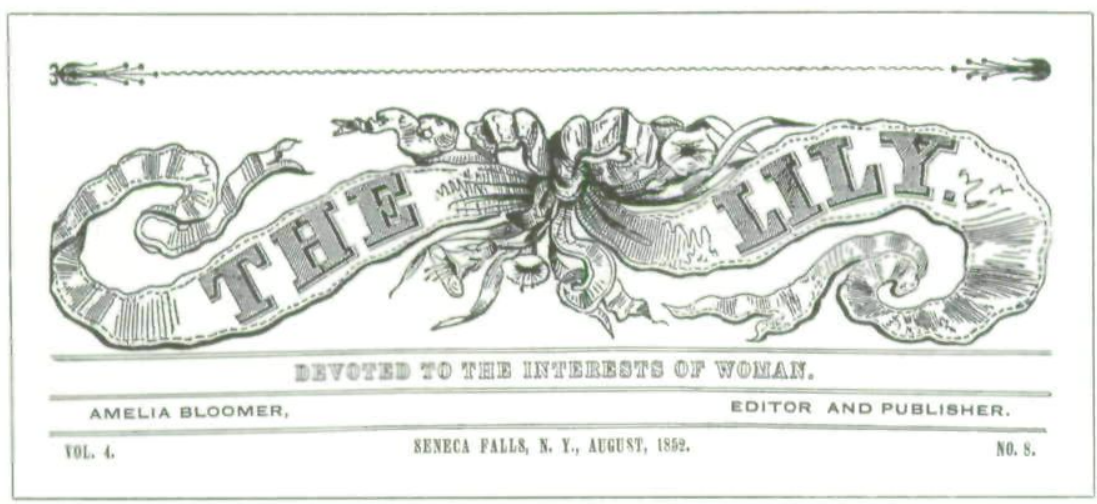

Anna Mattison, who was enthusiastic, Bloomer presented the idea to the society who greeted it with favor. They decided to begin publication the first of January 1849, with Bloomer and Mattison as co-editors. They christened the paper the Lily because that flower was an emblem of sweetness and purity, and the mission of the paper was "to sweeten and purify the home and to rescue it from the curse of intemperance as well as from the moral degradation of impure and unwholesome literature." 23

Dexter warned Amelia about the hazards of her undertaking. Publishing a paper was costly and it seemed likely that they could not generate enough subscriptions to meet expenses. The women of the society were so enthusiastic that they decided to take the risk and Bloomer, who assumed primary responsibility, issued a prospectus advertising the Lily at fifty cents a year, ordered a mast head from New York, and made a printing agreement with the Seneca County Courier. An itinerant temperance lecturer offered to get subscriptions wherever he went and the society gladly accepted. As soon as the women announced plans for the Lily, however, the temperance society received a storm of criticism. People characterized the idea as absurd. Women were not capable of managing such a project; it would be a failure from the start and the women connected with it would be subjects of ridicule. Women could exercise their influence in an appropriate and modest way, but

23. Amelia Bloomer to Elizabeth Harbert, (see n. 15); Lily, January 1849; Banner, Elizabeth Cady Stanton, 53-54; D. C. Bloomer, Life, 40; Chamberlain, "Seneca Falls Press," 5. 
to assume the sponsorship of a paper would cause more harm than good. Thoroughly intimidated, the society withdrew its sponsorship before the paper went to press. ${ }^{24}$

Bloomer felt she could not give up. She soon found that her co-editor, Mattison the poet, had no qualifications for her job beyond temperance zeal and Mattison's association with the paper became "in name only." Meanwhile their agent, the temperance lecturer, sent in the names of many subscribers but did not include the money he had collected from them. Yet despite these discouragements, the Lily appeared as planned on the first of January and continued regular publication under Bloomer's editorship for the next six years. Mattison resigned after the issuance of the second number. The paper carried the banner: "A Monthly Journal Devoted to Temperance and Literature" and announced that it was "Published by a Committee of Ladies." Despite her sole editorship, Bloomer used this committee head throughout 1849 , probably because a new one would have cost too much to typeset. She found enough subscribers to keep the paper going and by wrapping and mailing it herself so that she paid only for paper and printing, she was able to end the year with a small profit. She had proved to the skeptics that a woman could conduct a successful business. ${ }^{25}$

In her salutatory editorial Bloomer proudly announced that a woman's voice spoke through the Lily. She felt it necessary, however, to defend herself by explaining that since intemperance was the foe to woman's peace and happiness, women had the right to wield their pens for its suppression. It was perfectly proper, she said, for a woman to leave the modest retirement which so much became her sex in order to influence men to avoid the destroyer's path. Bloomer confined the first few issues of the Lily to the subject of temperance but within a few months her outlook seemed to be broadening. The May issue carried an article which deplored the nature of female education; women received instruction on how to please men rather than how to develop their own minds. In June Bloomer published an article about the value of physical exercise for women

24. Amelia Bloomer to Elizabeth Harbert; Chamberlain, "Seneca Falls Press," 5.

25. Bloomer to Harbert. 
and she wrote an editorial which lamented the double standard of morals for men and women. She continued to assert that women could use their moral influence to achieve reform. In September she told her readers that women had sufficient moral power to banish intemperance. A month later, she wrote that women needed to elevate their own characters and to learn to manage their own households properly before they could hold in their hands the reins of government. Yet in this same issue she moved nearer to the feminist position with a long editorial, "Woman's Rights," in which she condemned men's liquor laws which doomed drunkards' wives to misery. This article seems to be Bloomer's first endorsement of the term "woman's rights" even though she was not yet ready to embrace the cause in its broadest sense. The change in her thinking probably reflected the influence of Elizabeth Cady Stanton who began writing for the Lily in that same November. ${ }^{26}$

Amelia Bloomer and Elizabeth Cady Stanton finally met when Stanton came to Bloomer's office in the fall of 1849 with an offer to write for the Lily. They had missed each other before then, even at the 1848 convention, probably because of Seneca Falls' social stratification. Stanton felt tied to her home and growing family and wanted to publicize the woman's rights cause through her writing. Bloomer accepted her offer with some trepidation; she feared that Stanton might express her radical ideas too freely. Stanton began cautiously; her article in the November Lily was about temperance. It was the first in a series of conversations between a mother and her young son which ran for several months. Although the subject was innocuous, Bloomer was uneasy. When she welcomed the "Sunflower" (Stanton's pseudonym) editorially, Bloomer warned that as long as it acted in concert with the Lily, the Sunflower would be welcome on its pages, "But should it grow proud, and in its loftiness pressure too much, the Lily would chide and reprove." 27

26. Lily, January 1849.

27. "Mrs. Bloomer on Dress Reform," The Sibyl, September 1856, 43; D. C. Bloomer, Life, 46-47; Lily, November 1849; Stanton and Blatch, Elizabeth Cady Stanton, 1:150. 
Sunflower replied that she would not grow proud and demanding; she was merely a humble plant which furnished seeds for poultry and caged birds while the Lily was the emblem of royalty. How could the Lily fear a flower so unnoticed and unpraised? Bloomer's response revealed the insecurity she felt in her relations with this sophisticated woman. She said she had not intended to reflect on the Sunflower's obscurity or boast of the Lily's nobility. She had only thought of the lofty and dignified Sunflower looking down on those who did not aim to rise so high. It had never occurred to her that the Sunflower might be pining from neglect and looking with envy on her more lowly neighbors. ${ }^{28}$

Coyness was not natural to Stanton and she revealed more honest feelings about the Lily in a letter published under the pseudonym "Sam." "Some have found fault with The Lily's name and some with the size of its brain," she said. She predicted that in time some broader reform might find a place in the Lily's affections, and then like a woman entering into marriage, she must change her name. She also expressed hope for the brain which, like the hand, might grow with using. The identity of "Sam" puzzled Bloomer, and because she had several subscribers with this name, she asked assistance in identifying this person. Although "Sam" criticized the Lily's name and brain, Sam also asked women to support the paper for its fight against intemperance and its demonstration of a woman's ability to write in aid of suffering humanity. Even though the Lily's pages were not full of arguments for woman's rights, wrote Sam, its editor deserved support simply because she was a woman.

Stanton worked to win Bloomer's trust and to liberalize her views. She often visited with Bloomer in her office, which was a meeting place for women in the community, and she invited Bloomer to join the conversation club she led. Bloomer found great intellectual stimulation in this club which met in its members' homes every Saturday night to discuss social, political, and literary subjects. At every meeting a member presented a ten-minute essay and others commented upon it. Women as well as men took turns presiding and thus received exposure

28. Lily, December 1849. 
to some parliamentary procedure. According to Stanton, many young people who did not belong to the "first circle" of the village were members of this club and thus had access to a social and intellectual life from which town society would ordinarily exclude them. Stanton probably had Bloomer in mind when she made this observation.

The first three issues of the Lily for 1850 revealed that Stanton was making rapid progress in her campaign to bring Bloomer into the woman's rights camp. In a January article Sunflower complained that women were not represented in government and that government completely overlooked their rights and interests. Another Sunflower article in February discussed the lack of opportunities for women to develop their full potential. This same issue carried a letter from a Waterloo correspondent which asked for civil rights for women. In March Bloomer explained to her readers that although she had not said much on the subject of woman's rights, she saw and heard so much that was calculated to keep women down that she felt compelled to take a stand on what she considered just and right. She declared that the time had come to discuss woman's rights and for women themselves to enter the contest. ${ }^{29}$

Meanwhile, Bloomer faced criticism from her conservative readers for her association with Stanton and her increasing support of woman's rights. In April Bloomer commented that some of her gentlemen readers worried that she might injure herself and her paper by saying too much on behalf of woman's rights. They intimated that some other person controlled her. Bloomer wanted her readers to know that she was perfectly capable of managing her own affairs and that she alone controlled the columns of the Lily. She asserted that women were beginning to recognize their own inferior position but she wished more were willing to devote their talents to the good of their sex. In May she announced her conclusion that the temperance cause would never triumph until women could vote. Stanton's persuasive powers had at last born fruit. ${ }^{30}$

29. Stanton to Anthony, 2 April 1852, in Stanton and Blatch, Elizabeth Cady Stanton; D. C. Bloomer, Life, 131; Lily, January, February, March 1850; Elizabeth Cady Stanton, Eighty Years and More: Reminiscences, 1815-1899 (New York, 1898), 152-153.

30. Lily, April, May 1850. 
Although Bloomer stood with Stanton on the suffrage issue, a wide divergence still existed between their philosophies. Stanton sought suffrage for women as a fundamental right; Bloomer wanted suffrage as a means to an end. Stanton attacked Christianity as practiced in the churches for fostering woman's inferior position in all areas of life. Bloomer found great solace in religion and refused to make broadside attacks on churches. Although the majority of the clergy opposed humanitarian questions of the day and preached against them, many supported good causes, she argued. Like people in general, some ministers were conservative and bigoted, others were open and liberal. The existence of the former did not justify the condemnation of the latter. ${ }^{31}$

Stanton was also an abolitionist. Although Bloomer deplored slavery she did not favor the abolitionists' radical solution and she saw intemperance as a greater evil than slavery. Bloomer defended Stanton in the May 1850 Lily (Bloomer identified Stanton as "S" in this piece). She wrote that although Stanton was an out-and-out abolitionist who had endured ridicule and criticism for her warm friendship with former slave Frederick Douglass, she was sure Stanton would agree that people in the North had to reform themselves before they undertook to abolish slavery in the South. However cruel and revolting the condition of the slave, Bloomer asserted, a slave's burdens were light compared with those of a drunkard. Stanton probably would not have agreed with Bloomer on this issue. Stanton's attitude toward slavery was considered extreme in the 1850s, and Bloomer's was more typical of most reformers of the pre-Civil War era. ${ }^{32}$

By the end of 1850 Bloomer could look back on her two

31. Stanton to Anthony, 2 April 1852; D. C. Bloomer, Life, 162-163. Aileen S. Kraditor, in The Ideas of the Woman Suffrage Movement, 1890-1920 (New York, 1965), 44-46, divides women's demands for the vote into two categories: the natural right and the expediency argument. She notes that the natural right argument was paramount in the early days of the movement and that the expediency argument came to the fore after the beginning of the twentieth century. Both elements were always present, however. For Stanton and Anthony the natural right argument was primary but for Bloomer and other temperance women the expedience or usefulness of woman suffrage was the principal concern.

32. Lily, May 1850. 
years as editor of the Lily with a good deal of satisfaction. Despite her fear of failure, the Lily operated in the black and furnished a unique service to the woman's temperance movement. Yet at the end of each year Bloomer threatened in print to retire because of her health and the uncertainty of business. Letters of support from her readers encouraged her to carry on. "Don't you do it, Mrs. Bloomer," wrote Jane Swisshelm, the acerbic editor of the Pittsburg Saturday Visiter [sic], when Bloomer threatened to give up the Lily because of bad headaches. Bloomer replied that although she had hoped to retire quietly, she had become confident that she should continue. Yet even as the last issue of the year went to press, Bloomer announced that she was seeking a successor. ${ }^{33}$ She could not have known the fame that her journal would bring to her.

During the early months of 1851 the "reform dress" became a topic of interest in Seneca Falls. This costume, then considered daring, seems modest by today's standards. Often called the "Turkish dress," it consisted of a knee-length tunic worn loose or belted at the waist over Turkish pantaloons of the same material that might be gathered at the ankle or hang straight. It was in decided contrast to the conventional dress of the day when five or six layers of quilted, stiffly starched petticoats held out women's voluminous overskirts and tightly laced corsets held in their waists. A correspondent to the Water Cure Journal complained that the corsets were "filled with whale bones and other splints fit only to be used on the human frame in case of broken bones." A loose-hanging single-layer dress, however, might reveal something of the figure beneath. Exposure of any part of the leg to public scrutiny was unladylike. Women were to hide even their feet from public view. Yet the reform dress was a new fashion with a significant purpose. ${ }^{34}$

The Seneca Falls Courier published a tongue-in-cheek article which recommended the short dress and Turkish pantaloons

33. Amelia Bloomer to Elizabeth Harbert, in Lily, October, December 1850.

34. "Story of the Bloomer Costume," unidentified clipping (c. 1888), New York Historical Society; D. C. Bloomer, Life, 65-66; Harper Life and Work, 1:112; Water Cure Journal, February 1851, 31; "The New Costume," The Home Journal, 5 July 1851. This last article is a reprint of a Bloomer letter dated 19 June 1851 from the "Tribune," probably the New York Tribune. 
for women. Amelia Bloomer responded with pleasure and surprise at the editor's sudden enlightenment as she knew the Courier's opposition to woman's rights. She announced that she would support any move to bring dress reform for women. About this same time Elizabeth Smith Miller, a cousin of Elizabeth Cady Stanton, who had been wearing the reform dress for a few months, visited Seneca Falls. Miller soon persuaded Stanton to make a short dress and pants for herself. In the February Lily Bloomer reported that several women in the village were ready to don the Turkish dress as soon as they could muster courage enough to appear publicly in the costume. Shortly after this announcement, Elizabeth Cady Stanton (who was eight months pregnant) and her cousin appeared on the main street of Seneca Falls in their reform dresses. ${ }^{35}$

"Never shall I forget this first appearance," recalled Mary Bull. "Mrs. Stanton is not slight or sylph-like in her proportions. ... Imagine her, then, in a full black satin frock cut off at the knee, with Turkish trousers of the same material, her wrap a ... shawl, and on her head the hideous bonnet then in fashion. I have seen scarecrows that did credit to farmers' boys' ingenuity," Bull continued, "but never one better calculated to scare all birds, beasts, and human beings than was Mrs. Stanton in the Bloomer dress." Stanton and her cousin "were followed by a crowd of boys yelling, singing and laughing, while every door and window was lined with staring faces. The whole town was roused as never before," Bull reminisced with what may have been a bit of hyperbole. To complete her emancipated costume, Stanton had also cut her hair. ${ }^{36}$

The Courier promptly challenged Amelia Bloomer to practice what she preached by donning the reform dress herself. Bloomer accepted the challenge and in April announced that she too was wearing the short dress. She had already become so attached to it that she disliked changing to a long one. Bloomer, with her petite figure and small feet (which were considered fashionable), looked much better in the short dress than did the short, plump Stanton. Mary Bull recalled that

35. D. C. Bloomer, Life, 66; "Story of the Bloomer Costume"; Stanton and Blatch, Elizabeth Cady Stanton, 1:171.

36. Bull, "Woman's Rights." 
Bloomer looked far better than any other person she had seen wear the costume. Unlike Stanton, however, Bloomer did not cut her hair. ${ }^{37}$

Excitement over the reform dress soon spread far beyond the Seneca Falls region. The telegraph and the recently established Associated Press carried the news across the United States and to Europe. On April 25, for example, the Dubuque Tribune reported that the editor of the Lily had adopted the short dress and pants. The Tribune quoted Bloomer as saying "Those who think we look queer would do well to look back a few years, at the time they wore ten or fifteen pounds of petticoats and bustle around the body, and balloons on their arms, then imagine which cut the queerest figure, they or we." The Tribune reported on June 25 that the new costume was spreading like prairie fire. The reform dress quickly became identified with Bloomer. "Like Byron, she went to rest all unconscious of greatness, and awoke one morning to find herself famous," commented the American Phrenological Journal. The New York Tribune at first referred to the reform dress as "Bloomer's Turkish Trousers." In July 1851 the Cincinnati Gazette reported several names suggested for the new costume, including the "Bloomer," the "Camilla," and the "Tom Boy." This newspaper preferred the last of the three. That same month the Burlington Telegraph announced that the new style had taken the name of its projector, Amelia Bloomer. ${ }^{38}$

Many viewed the reform dress as shocking, especially because it did not conceal women's legs. A young woman reported that in Wisconsin a few truly modest women were wearing the new costume; they thought it not unbecoming to let others know they had legs. In England, Lady Chesterfield called the Bloomer dress absurd and immodest, and said that it would cause ribald comments from men about parts of ladies' dress of which they ought to remain ignorant. Critics wondered why, if convenience was their concern, women did not just shorten their dresses two or three inches to keep them from

37. E. Douglas Branch, "The Lily and the Bloomer," The Colophon, December 1932; D. C. Bloomer, Life, 67.

38. "Character and Biography" American Phrenological Journal; New York Tribune, 12 June 1851; Dubuque Weekly Tribune, 16 July 1851 (reprint from Cincinnati Gazette); Burlington Telegraph, 26 July 1851. 
sweeping the pavements, instead of cutting them so short and wearing pants. Bloomer explained that shortening dresses would not rid women of the heavy underskirts which they wore to keep clothing from clinging to the body. By shortening skirts to the knee and wearing pants underneath women had freedom of movement and relief from the weight of petticoats suspended from the waist. Even a woman in a short dress and trousers was not as immodest as a woman wearing a long clinging skirt would be, Bloomer contended. When a clergyman quoted Moses as an authority against women wearing men's attire, Bloomer told her readers that what Moses said to the men and women of his time was irrelevant. Common sense told her that men and women should wear the most convenient clothing and if divine vengeance were ever visited upon woman because of the cut of her garments, it would be upon the wearers of the suicidal, long, heavy skirts rather than upon those who had rid themselves of that grievous burden. ${ }^{39}$ "Mrs. Bloomer is evidently proud that this attire has been given her name," Elizabeth Cady Stanton wrote to her friend Amelia Opie in September 1851. "In fact," said Stanton, "Mrs. Bloomer who is very pious is beginning to think that the dress is almost of divine origin and blames woman who dares to call down before herself the wrath of the Almighty for ... mutilating and destroying the work which came perfect from his hand." Stanton would not go quite so far, but on balance, she credited Bloomer and her little paper with a good work. She felt like Frances Dana Gage, the feminist author, who on seeing the Lily for the first time, exclaimed

Oh listen to the fairy within The Lily's bell

She sings of Human Progress and she sings it well. ${ }^{40}$

Critics charged that the Bloomer dress was the result of woman's rights agitation. Women were wearing pants, the symbol of male authority, and the costume soon became known

39. The Liberator, 20 June 1851 (reprint from the New York Tribune); "On Beauty and Legs," unidentified clipping, James Callanan scrapbook, ISHDDM; "New Costume," Home Journal: D. C. Bloomer, Life, 77-78.

40. Elizabeth Cady Stanton to Amelia Opies, 30 September 1851, Elizabeth Cady Stanton Papers, Library of Congress. 
as the badge of female radicalism. Cartoonists lampooned the dress by drawing Bloomer-clad women as prizefighters or cigarsmoking politicians while they portrayed men at home rocking the cradle. Reform dress was the subject of a farce, "The Bloomer Costume or the Figure of Fun," and, in Boston, wags decked out prostitutes in the short dress and pants and sent them out on the street. Even Dexter Bloomer was the subject of doggerel such as, "He is henpecked to the soul because he has lately been brought under proud woman's domestic control." The Bloomer costume also became the subject of a brief, frivilous fad in 1851 during which men organized Bloomer balls and challenged women to attend in the reform costume. Bloomer polkas, Bloomer waltzes, and Bloomer schottisches were popular. A song, "The Bloomer Complaint," appeared, and Currier, not yet in partnership with Ives, published a print of a woman in Bloomer dress. ${ }^{41}$

At the same time that critics lampooned, cartooned, vilified, and made fun of the Bloomer dress, it met a warm reception from hundreds of women throughout the United States who, seeking relief from the bondage of current fashion, wrote to the Lily for instructions to make the new dress. Since Bloomer could not answer them all personally she had a detailed description printed and announced in the Lily that copies were available at twenty-five cents each. As a result of the furor over the Bloomer costume, the number of subscribers to the Lily also rose dramatically and the paper soon became the unofficial organ of dress reform. Yet most of the women who dared appear in the reform dress soon ceased to wear it. Elizabeth Buffum Chace, a Rhode Island feminist, ventured outdoors in the dress only once, but felt so conspicuous that she never

41. Tyler, Freedom's Ferment, 440-441; "Woman's Emancipation," cartoon, Harper's Monthly, August 1851, 424; Edmund Stirling, "The Bloomer Costume or the Figure of Fun, An Original Farce in One Act" (New York, [1851?]) originally no. 43 in F. C. Wemyss, ed., The Minor Drama; Branch, "The Lily and the Bloomer"; James B. Weaver, "The Full Tide," Palimpsest 14 (January 1933), 11. The New York Historical Society has a collection of sheet music which the Bloomer dress inspired, such as "Bloomer or New Costume Polka" (New York: Firth, Pond \& Co., 1851); "Bloomer Waltz" (New York: Wm. Hall \& Son, 1851); "The Bloomer Polka and the Bloomer Schottische" (London: Musical Bouquet Office, n.d.); and "The New Costume Polka" (New York: Wm. Hall \& Son, n.d.). See also cartoon, Harper's Monthly, August 1845, 424. 


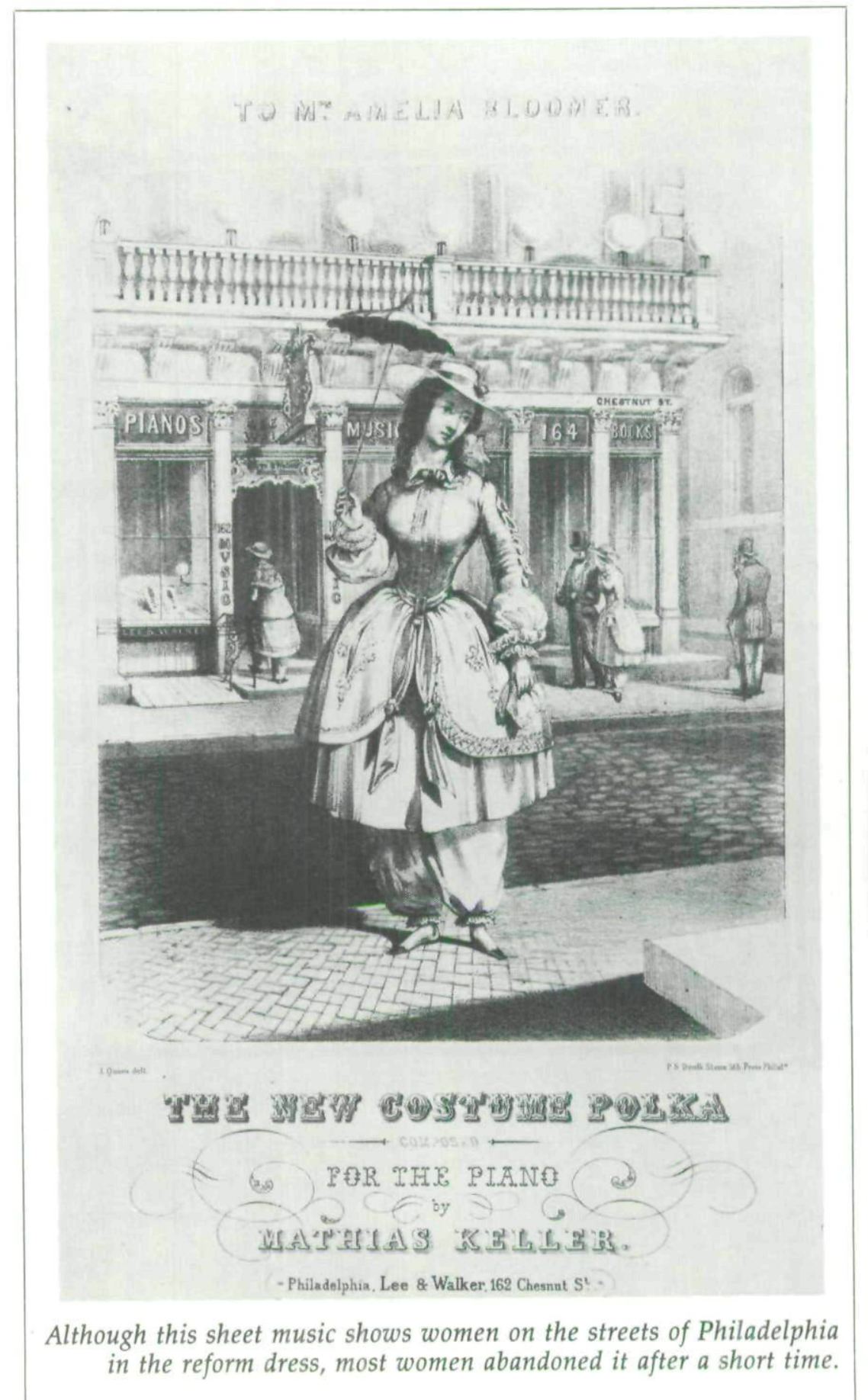


wore it in public again. Pittsburgh editor Jane Swisshelm made one of the dresses but wore it only briefly. The costume was fine for young girls, but not for a woman of thirty-four, she said. She thought it would be good for walking or working, but she did not have the courage to brave public ridicule. ${ }^{42}$

A few leaders of the woman's rights movement, including Elizabeth Cady Stanton, Susan B. Anthony, and Lucy Stone, wore the reform dress for several years. Since they adopted it as a matter of principle, they felt they must wear it despite the jibes and jeers. "For it they suffered a martyrdom which would have made burning at the stake seem comfortable," wrote Ida Husted Harper, Anthony's friend and biographer. As long as they felt that wearing it helped the woman's rights movement they were willing to brave public ridicule, but when they realized that it was hindering rather than helping their cause they returned to conventional clothing. Stanton gave up the Bloomer dress by the end of 1853 and most of the other women soon followed. ${ }^{43}$

Bloomer wore the reform dress longer than any of her cohorts and felt no martyrdom in doing so. She believed that a change in woman's style of dress was necessary and that she could set an example. She seemed to thoroughly enjoy the distinction which the costume brought her and she did not lay it aside until some time after her move to Iowa in 1855. Summing up the exciting events of 1851 , she told her readers that she had experienced more pleasure than pain. Although she might have demurred from wearing the dress had she anticipated the consequences, she had survived unscathed. The trial had strengthened her and she had enjoyed the editorial crossfire and sallies of wit and sarcasm even when aimed at her. In January 1852 the Lily boasted a new head with a banner that read: "Devoted to the Interests of Woman." 44

Amelia Bloomer's increasing devotion to the woman's movement coincided with a shift in her estimation of the most

42. D. C. Bloomer, Life, 68; "Story of the Bloomer Costume"; Lucy Buffam Chase and Arthur Crawford Wyman, Elizabeth Buffam Chase (Boston, 1914), 1:113; Iowa State Journal (Des Moines), 13 July 1851.

43. Harper, Life and Work, 1:114-115.

44. D. C. Bloomer, Life, 72; Lily, November 1851. 
effective means of temperance reform. The temperance movement itself was becoming political, as its proponents depended less on religiously inspired personal abstinence and instead looked to government to stop the liquor traffic. In February 1846 the New York legislature passed a local-option law, but repealed it the following year. Temperance advocates then began to campaign for statewide prohibition. The enactment of a strict prohibition law in Maine in 1851 encouraged them to obtain the same kind of law in New York as well. ${ }^{45}$

Women were increasingly active in the temperance cause in New York State and, after campaigning for the local option in 1846 , they were indignant when the legislature repealed it. Some women manifested their outrage by visiting saloons, where they broke bottles and emptied barrels of whiskey into gutters. More sedate women organized themselves into societies called the Daughters of Temperance. The Sons of Temperance, to which the Daughters were subordinate, had organized in 1842 in the wake of the Washingtonian movement as a secret, fraternal society with uniforms, sickness and death benefits, and closed meetings. They published a paper, the Temperance Star, for which Amelia Bloomer wrote contributions. Like the Sons, the Daughters also formed a secret organization, but held no official standing in the parent organization. Although the Daughters had no branch in Seneca Falls, Bloomer was in touch with members in other communities through her Lily. As temperance work became increasingly political, Bloomer came to see the futility of women's traditional role as moral reformers. She told her readers in April 1852 that she could see no virtue in trying to rescue the victims of drink as long as men licensed its sale. The effective remedy for intemperance, she was realizing, lay with those who could vote. ${ }^{46}$

Mary Vaughan of Oswego, a future leader in the temperance movement, came to the same conclusion. Although she chastised the Lily in November 1851 for neglecting temperance reform in favor of woman's rights, she stated at the same time

45. Standard Encyclopedia of the Alcohol Problem, 1941-1942.

46. Stanton et al., History of Woman Suffrage, 1:474-475; Rose Evans Paulson, Woman Suffrage and Prohibition: A Comparative Study of Equality and Social Contract (Glenview, Ill., 1973), 70; Harper, Life and Work, 1:62; Lily, November 1850. 
that the temperance movement would not prevail until women could vote. This position, even a year earlier, would have been abhorrent to her. What women like Bloomer and Vaughan needed, however, was a leader who could harness their desire for political action into an effective working organization. In 1852 such a leader arose: Susan B. Anthony of Rochester. Two years younger than Bloomer, Anthony was tall, blunt, determined, and direct. Her parents were liberal, antislavery Quakers who wholeheartedly supported her reform activities. She had begun teaching away from home at an early age and soon discovered, much to her indignation, that women earned less as teachers than did men. ${ }^{47}$

Anthony had left teaching in the fall of 1849 and returned to Rochester to help manage her parents' farm. The Anthony home became the gathering place where leading reformers of the day discussed temperance, antislavery, and woman's rights issues. Embued with a desire to take an active part in these reforms, Anthony found the Daughters of Temperance to be the only outlet for her energies. She enthusiastically joined in the work of this organization, raised funds, and organized chapters in nearby communities. During the course of this work she met Bloomer. Although sympathetic to woman's rights, Anthony did not take an active part in the movement until after she met Stanton in May 1851. Bloomer introduced them when Anthony, who had come to Seneca Falls to attend an abolition meeting, was staying in Bloomer's home. Anthony and Stanton immediately liked each other and soon began working as a team, first in temperance activities, then shifting their entire energies to woman's rights. ${ }^{48}$

In January 1852 Anthony, Mary Vaughan, and other Daughters accepted an invitation from the Sons of Temperance to attend a statewide meeting in Albany. The intent of the meet-

47. Lily, November 1851; James, Notable American Women, 1:51-52.

48. James, Notable American Women, 52; D. C. Bloomer, Life, 54. Both sources place Anthony's and Stanton's first meeting in 1850. The correct year is 1851, however. See Banner, Elizabeth Cady Stanton, 179, and Harper, Life and Work, 64. This error stems from Stanton's reminiscences in the History of Woman Suffrage, 1:456, where Stanton gave the incorrect date. When Bloomer called her attention to the error, Stanton replied that Bloomer was right, although she had never noticed the error herself. (Stanton to Bloomer, 10 November 1881 or 1882 .) 
ing was to promote a Maine law for New York. The Daughters carried letters from Bloomer and Stanton to read to the Sons. When Anthony rose to speak to a motion, however, the presiding officer told her that the Sons had not invited the Daughters there to speak, but to listen and learn. Anthony, Vaughan, and several other women left the hall in protest. That evening they called a meeting of their own in a dismal church parlor. Vaughan presided, and when they decided to form an independent women's state temperance organization they appointed Anthony chair of a committee to arrange a convention. The gathering listened to a reading of Bloomer's letter but there were objections to also hearing Stanton's letter because it advocated divorce for drunkards' wives. At this time a wife was by law completely subservient to her husband no matter how degenerate he might be; she had no rights to either her own earnings or to the custody of her children. New York law only permitted divorce in cases of adultery and most respectable persons considered divorce a sin under any circumstances. In spite of the objectors, however, Anthony read Stanton's letter to the gathering. The Lily subsequently published it and the press generally condemned it. ${ }^{49}$

Anthony worked tirelessly during the next few months making arrangements for the state convention at Rochester on April 21 and 22. She looked to Bloomer and Stanton for help in this project but soon found that they had fundamental differences on women's roles as temperance advocates. Stanton wanted to use the temperance movement to radicalize women concerning their inferior position in society. Bloomer was willing to accept many of Stanton's ideas, but her primary objective was to promote temperance, not woman's rights. In early April, Stanton warned Anthony against reliance on Bloomer's advice. Stanton told Anthony to take Bloomer's suggestions only with great caution because Bloomer did not have the spirit of a true reformer. Only with great effort and patience, Stanton claimed, had she even brought Bloomer up to her present position. Stanton complained that Bloomer would neither speak out against the Fugitive Slave Law nor criticize the church's equivocal position on the slavery question. Stan-

49. Stanton et al., History, 1:64-65; Harper, Life and Work, 1:61, 64-7, 74. 
ton did not want to injure Bloomer, yet she was wary of her conservative suggestions. Stanton intended to challenge the church at the coming convention because it was such a terrible engine of repression. ${ }^{50}$

The woman's temperance meeting in April drew large audiences. Between four and five hundred attended the organizing session which the committee restricted to women. As many as fourteen hundred people were present at the five other sessions. Stanton presided, dressed in a black, short dress and trousers of the same material. The organizing meeting adopted a constitution for a Woman's State Temperance Society which opened membership to all women who wanted to join. This contrasted with the secret societies which Stanton had found offensive. Men could be members of the new society but they could neither vote nor hold office. The society elected Stanton president; Bloomer, corresponding secretary; and Anthony and Vaughan, recording secretaries. ${ }^{51}$

Events diminished the historical significance of this organization because Anthony and Stanton defected the following year, yet it was an important milestone in the development of women's self-reliance. The New York State Men's Temperance Society had existed for more than twenty-five years, but this convention marked the first occasion on which temperance women came together on a statewide basis. For Bloomer and most of the others it was also their first experience with large-scale organization, parliamentary procedure, and speaking in public. Dexter Bloomer considered this convention the most important event in the expansion of women's horizons. Although the woman's rights advocates had a broader view of the work ahead than did traditional temperance workers, all of the participants devoted themselves to their common cause with great earnestness. Amelia Bloomer, Dexter recalled, always looked on her association with this society as one of the most useful in her life. ${ }^{52}$

50. Harper, Life and Work, 67; Stanton to Anthony, 2 April 1852.

51. Stanton et al., History, 1:480-482; Lily, June 1852.

52. Standard Encyclopedia of the Alcohol Problem, 1941-1942; D. C. Bloomer, Life, 89. The Encyclopedia does not mention women's temperance work in New York State until 1873, which may indicate pre-Civil War era disregard for that work. 
Stanton, of course, was one of those who took the wider view. Although she did not mention the controversial term "woman's rights" in her salutatory address, she advised the women that a just appreciation of individual rights was the true basis for all reform. She tested the church by proposing a resolution which stated that no one could force a woman to have a child by a drunken husband and that drunkards' wives should have the right of divorce. Her resolution also proposed that women should withdraw support from churches and foreign missions and devote their efforts to helping the poor and suffering at home. The resolution stated that good schools and homes would do much more to prevent immorality and crime than churches could ever accomplish. ${ }^{53}$

Bloomer made her first public address to this convention. She did not comment on Stanton's suggestion that women should withdraw their support from churches, although we may speculate that she privately deplored it. She did, however, endorse Stanton's position that wives of drunkards should have the right to divorce their husbands. Although such a sentiment shocked the moral sense of society, she reasoned, divorce was preferable to compelling a woman to spend her life tied to a drunkard's "filthy carcass." Bloomer even advocated that divorce be compulsory in cases of drunkenness, especially if there were children involved. Bloomer also argued that women should have political rights if they were to be effective temperance workers. ${ }^{54}$

The convention authorized the employment of six agents at twenty-five dollars a month to promote the association's work. Anthony assumed primary responsibility for the organizational work and during the year she and other society agents visited nearly every county in the state, formed auxiliaries, circulated tracts and petitions, and sold Lily subscriptions. Anthony urged local societies to subscribe to the Lily "because it is particularly devoted to woman's interest in temperance and kindred reforms, and because it is their duty to sustain the only paper in the state owned and edited by a woman." By the end of the year the number of subscribers to the Lily had risen to two thousand. ${ }^{55}$

53. Lily, May 1852; Stanton et al., History, 1:482-483.

54. D. C. Bloomer, Life, $87-88$.

55. Stanton et al., History, 488-489. 
In June of 1852 Bloomer and Anthony attended the men's state temperance convention in Syracuse as delegates from the Woman's State Temperance Society. They went in response to an invitation to all temperance societies to participate but they anticipated that the men would challenge their credentials as delegates because of their sex. The presence of these two women caused great consternation among the clergy in attendance; most of the day's meeting consisted of a raucous discussion of what to do about these two females sitting sedately segregated with other women visitors at one side of the platform. Male delegates called the rising independence of women an abomination and said that they must tear this movement up, root and branch. The chair ruled against the women's participation in the meeting. He said that although the constitution of the society did not prevent women from speaking and voting as men, its spirit did not give females such rights because, at the time of its writing, no one had imagined that women ever would speak in public. A minister then offered his church to Bloomer and Anthony for an evening meeting which drew a much larger crowd than the men's convention. Amelia Bloomer's activities during this eventful year left her in a state of exhaustion and she spent six weeks in the fall of 1852 under the treatment of a Dr. Hamilton in Rochester. She continued to edit the Lily from Rochester, however. ${ }^{56}$

In January 1853 Bloomer attended a large meeting of women temperance advocates in Albany where the legislature was in session. The high point of this meeting occurred when Bloomer and two other women, by previous arrangement, were allowed on the House floor to present petitions for a prohibition law. These petitions carried the signatures of 28,000 women and were each neatly rolled, tied with ribbon, and marked with the name of the community of origin. Bloomer's two cohorts carried them to the podium in a large two-handled basket. This was the first time in New York's history that women had appeared before the legislature. They naively expected that the legislators would grant their request in a short time, but soon learned the realities of the world of politics.

56. Amelia Bloomer, "A Reminiscence," Woman's Standard (Des Moines, Dec. 1887), 2; Stanton et al., History, 487-489; Lily, October 1852. 
"Alas," Bloomer later commented, "what cared our so-called representatives for the petitions of a disfranchised class?" The Albany State Register described Bloomer, who also addressed the women's convention in Albany, as suprisingly modest in appearance: not the bold, loud-mouthed woman many had expected. ${ }^{57}$

At this meeting in Albany, Bloomer and other delegates became acquainted with S. P. Townsend, a millionaire manufacturer of Sarsaparilla. Townsend invited Bloomer, Anthony, and Antoinette Brown to New York to lecture on temperance. $\mathrm{He}$ offered to make all of the arrangements for their appearance and to underwrite their expenses; the three women could divide the profits. They accepted this invitation and Anthony arranged a two-week tour to begin in New York City in early February of 1853 . There they were guests of Lydia Fowler, a pioneer female physician married to Lorenzo Fowler, a noted phrenologist. The first public appearance on the lecture tour was on February 7,1853, in Metropolitan Hall, where no woman had ever lectured. Bloomer, Anthony, and Brown drew an audience of three thousand who paid twenty-five cents each to attend. Many were curiosity-seekers interested in female lecturers, especially in those wearing the reform dress. (Brown, an ordained minister, refused to don the costume.) Lydia Fowler presided at the meeting and a number of well-known New Yorkers sat on the platform, including Horace Greeley, the famous editor. Greeley gave the women extensive publicity in his paper, the New York Tribune. ${ }^{58}$

The Tribune described the reform dress which Bloomer wore at Metropolitan Hall as a dark-brown changeable material consisting of a tunic which reached just below her knees over pants of the same material. Both garments were trimmed with rows of black velvet. A white "chemisette" adorned with a diamond stud pin filled the large, open bodice. Under the wide sleeves of her dress Bloomer wore tight undersleeves. Com-

57. Stanton et al., History, 1:489; D. C. Bloomer, Life, 95; Lily, February 1853; "Ladies State Temperance Convention," unidentified clippings dated Friday, 21 January, James Callanan scrapbook, ISHD-DM.

58. Harper, Life and Work, 83. Antoinette Brown became the first female minister of a recognized denomination in the United States when the Congregational Church ordained her in September 1853. Lily, 15 February 1853. 
pleting the outfit were lace mits, gaiters, and a cherry red and black hat. Her costume, the Tribune said, was rich and plain in appearance. ${ }^{59}$

After leaving New York City the three women visited Troy, Poughkeepsie, Sing Sing, and Peekskill, and drew large audiences wherever they went. In early March Bloomer, Anthony, and Brown made a second tour in New York State, and again began in New York City where they spoke at least twice. This time Horace Greeley invited them to spend an evening in his home along with a number of prominent literary people. The immodest dress of the poet-sisters, Phoebe and Alice Cary, shocked Bloomer. They appeared in low-necked sleeveless gowns with trailing skirts. The Cary sisters, Bloomer later commented, were no doubt as much disgusted with her short dress and trousers (which left no part of the body exposed) as she was to see women in company half-dressed. ${ }^{60}$

On this second departure from New York City, the trio addressed large audiences at Hudson, Cohoes, Troy, Utica, Rochester, and Buffalo. In the last-named city over a thousand people turned out to hear them and they thus immediately scheduled more meetings. Bloomer, Anthony, and Brown lectured on temperance and the need for a Maine law but also asked for woman's rights as a step toward temperance goals. At Cohoes, Bloomer told her audience that woman had to assert herself as a being equal to and as responsible as man and claim the right to a voice in the administration of all laws that affected her interest. An admirer in the Cohoes audience described Bloomer as "graceful, of rather coquettish mien, a slight figure, and elegant form. Her dress becomes her admirably." Bloomer's small feet reminded this writer of Sir John Suckling's little mice playing at "bo-peep." 61

Bloomer and her cohorts also used their lecture tours to

59. D. C. Bloomer, Life, 102-103.

60. Lily, 1 March, 15 March 1853; Harper, Life and Work, 83; D. C. Bloomer, Life, 100-101.

61. Harper, Life and Work, 83; "All About Mrs. Bloomer," unidentified clipping, Amelia Bloomer scrapbook, Council Bluffs Free Public Library. This clipping is dated 11 March 1852, but the year may be a typographical error since Bloomer had not made a public address at that time. The year should be 1853 . 
promote the Woman's State Temperance Society and to sell subscriptions to the Lily. According to Bloomer's admirer in Cohoes, a good many women subscribed to the Lily after her lecture there, but only a few became members in the temperance society. This lack of support for the state society annoyed Anthony, who reassured prospective contributors not to fear that the speakers would use the money to purchase ribbons and laces for themselves. She and her companions could afford to pay for their own fineries. ${ }^{62}$

Amelia Bloomer and the more conservative temperance advocates faced a showdown with Elizabeth Cady Stanton at the first annual meeting of the Woman's State Temperance Society in Rochester, New York, on June 1 and 2, 1853. Stanton answered her critics in her salutatory address to the convention. She said some people had objected that she did not confine her efforts to temperance alone, that she talked too much about woman's rights, divorce, and the church. She told the convention that people who worked for temperance alone were superficial reformers in that they would treat symptoms, while those who advocated wider reforms would cure the fundamental evils of society. Those who preferred to work for temperance only, she admonished, should not prevent others from pointing out the basic causes of this evil. ${ }^{63}$

Stanton's critics wanted to prevent her reelection to the office of president, but they did not know the parliamentary procedures this would require. They sought the assistance of some of the men at the meeting who helped them put together an opposition ticket headed by Mary Vaughan. They had this ticket printed, while the nominating committee for Stanton presented theirs orally. Vaughan defeated Stanton by three votes. The convention chose Stanton vice-president, but she refused the position. Vaughan, as the new president, infuriated Stanton and Anthony by declaring that one must at times sacrifice principle for the sake of expediency. Anthony also refused the office of secretary to which the convention had reelected her, and announced that "her soul was not with this society and there was no use keeping her body there." 64

62. Ibid.

63. Stanton et al., History, 1:495; Buhle and Buhle, Concise History, 147-149.

64. Harper, Life and Work, 1:92-95; Lily, fire-damaged copy, probably June 1853. 
Bloomer later reported in the Lily that she had expressed her views on the association's leadership in committee but she remained silent during the arguments on the convention floor. Her husband, however, indirectly endorsed the opposition slate by telling the convention, which had admitted men as voting members, that he intended to vote for the printed ticket because doing so would save writing a long list of names. Nonetheless, added Dexter, he hoped no one would support this slate who did not like it. As a consequence of her silence, many thought Bloomer sided with the Stanton-Anthony faction; her sympathies and her vote went with the Vaughan forces, however. This meeting reelected Bloomer corresponding secretary, a position that she held until she moved from the state later in the year. ${ }^{65}$

Some might regret the loss of Stanton as president, Bloomer commented in the Lily. She was sure, however, that in this case the convention could have made no better choice than Vaughan. In an obvious reference to Stanton's fight to keep her own office, Bloomer said she was sure that when Vaughan's term of office expired she would retire with cheerfulness and grace. To explain her priorities, Bloomer told her readers that as great as was her faith in the ultimate triumph of temperance principles once women had the vote, that day was too far distant to justify confining their efforts to that issue alone. Women were to gradually prepare themselves for the franchise and show they were capable of exercising it. Frances Dana Gage, the feminist author, agreed with Bloomer's position. In response to a letter from Bloomer about the convention, Gage regretted that women could be so selfish as to let their own interest militate against the holy cause of temperance. If she could not work for both woman's rights and temperance at the same time, she wrote, she would put woman's rights aside until a temperance victory occurred. In answer to what was probably a question of Bloomer's about the attitude of Stanton and Anthony, Gage remained emphatic in her belief that the two women were sincere. ${ }^{66}$

65. Lily, June 1853.

66. Lily, June 1853; Frances Dana Gage to Amelia Bloomer, 22 June 1853, Council Bluffs Free Public Library. 
After the 1853 Rochester temperance meeting, Stanton and Anthony, who considered woman's rights their primary objective, ceased attempts to effect a coalition with temperance forces. Stanton's contributions to the Lily, which had steadily declined in frequency during the year, disappeared entirely. This convention also marked an end to joint appearances of Bloomer and Anthony on the lecture platform; Anthony then directed her efforts almost entirely to the woman's rights cause and Bloomer continued to lecture on her own. ${ }^{67}$

In the latter part of June, Bloomer spoke at the first state convention of the Good Templars in Utica, where she was a delegate from the organization's Seneca Falls chapter. The Good Templars began in Onandaga County, New York, in late 1852 , and soon spread over adjacent counties. It was the first temperance society to admit both women and men to membership on an equal basis. Dexter and Amelia joined as soon as a chapter formed in Seneca Falls. As liberal as this organization's policy was toward women, it imitated traditional temperance societies in its secrecy and exclusiveness. Bloomer defended her association with a secret organization because the society accomplished much for the temperance cause. When the scheduled speaker for the Good Templar's convention in Utica did not appear, members asked Bloomer to take his place. The church at which the Good Templars were meeting, however, refused to allow a woman to speak. The Baptist church in town came to the rescue and offered its building where Bloomer spoke to a large crowd. ${ }^{68}$

Bloomer also was the featured speaker at a Fourth-of-July celebration in the town of Harford. She marched in a parade led by a band and followed by Good Templars and Sons of Temperance dressed in the regalia of their orders. A committee of women in short dresses and pants escorted her to the speakers' stand. There were from fifteen hundred to two thousand in the audience, according to estimates. Then in September, Bloomer was again the guest of Lydia Fowler in New York

67. Harper, Life and Work, 95. Banner notes that Stanton allied herself with the temperance forces to gain support for feminism, but that she failed because she had not yet realized the conservatism of women (Banner, Elizabeth Cady Stanton, 54-55).

68. Harper, Life and Work, 95; D. C. Bloomer, Life, 115-118. 
City. Bloomer, Vaughan, and Emily Clark, all officers of the Woman's State Temperance Society, spoke to a large audience at the Broadway Tabernacle. Bloomer also attended two temperance meetings: the World's Temperance Convention, which refused to admit women delegates, and the Whole World's Temperance Convention, organized by women and men who objected to the exclusionary policy of the all-male gathering. Bloomer made a short address to the latter assembly. She enjoyed meeting many temperance workers who previously were known to her only by name, including her correspondent, Frances Dana Gage. Bloomer also visited the world's fair and participated in a vegetarian banquet, although she did not attend the woman's rights convention which met in New York immediately after the temperance meetings. ${ }^{69}$

Shortly after her New York visit Bloomer and her husband, who once again had the western fever, made an extended trip west and she lectured along the way. After a number of appearances in Indiana and Ohio, they went on to Detroit, Chicago, and Milwaukee, where Bloomer spoke at least once and sometimes twice in each community. With the possible exception of Lucy Stone, Bloomer was the first woman to lecture in these cities. At Cleveland in early October, Bloomer spoke to the fourth national woman's rights convention. This was her first appearance at an annual woman's rights meeting. She also delivered two temperance lectures there, one before a mass convention of male temperance advocates who invited her as a demonstration of their liberality toward women (in contrast to women's exclusion from the recent New York world's temperance meeting).$^{70}$

Although all of her lectures could not have been as remunerative as her first appearance in New York City when a millionaire met the expenses, lecturing was doubtless a good source of income for Bloomer during 1852 and 1853. Women on the platform were novelties, especially women in short dresses and pants, and people flocked to see and hear them. In some places local organizations sponsored speakers and

69. Harper, Life and Work, 87-89; D. C. Bloomer, Life, 123-124, 133-136; New York Herald, 6 September 1853; Tyler, Freedom's Ferment, 449-450.

70. D. C. Bloomer, Life, 140-142, 137-139. See also Amelia Bloomer, temperance lecture. 
paid them fixed fees, but more often lecturers had to pay all of the expenses connected with their appearances. They were then entitled to any profits. Thus Bloomer's reform work opened a source of income for her in an area where few women had ventured. Nevertheless it was exhausting work. After Bloomer returned to Seneca Falls late in the autumn of 1853 she spent several weeks at Dr. Jackson's water cure on Lake Skaneateles, where she found a quiet, congenial atmosphere in which to recuperate. ${ }^{71}$

During the Bloomers' western trip in the fall of 1853 Dexter purchased a half-interest in a weekly reform paper, the Western Home Visitor, published in Mt. Vernon, a community of about six thousand in southern Ohio. At the same time, Amelia arranged a Mt. Vernon office for the Lily and planned to print her paper on the new steam press which Dexter and his partner owned. The Bloomers had decided to leave Seneca Falls, probably because Dexter lost his postmastership when the Whigs went out of office in the spring of that year. ${ }^{72}$

The Good Templars of Seneca Falls sponsored a farewell temperance banquet for the Bloomers who were to leave for Ohio on Christmas Day. Five hundred people attended. After the testimonials of friends, music and dancing continued until a very late hour. Bloomer's mood, however, was not jubilant. She grieved over leaving the state where she had always lived, the community of which she had been a part for fourteen years, and the home on Bayard Street which she had enjoyed so much. Bloomer announced her departure in the December 1853 Lily and called this move the greatest sorrow ever laid upon her. Despite her agony at having to leave those she loved, however, she believed that as a true and faithful wife she was bound to say, in the language of Ruth, "Where thou goest, I will go." In bidding Bloomer farewell, Isaac Fuller, editor of the Courier, noted that the Lily, whose current circulation was over four thousand, had given the village of Seneca Falls wide publicity which it would not otherwise have had. Although he disapproved of some of the Lily editor's views,

71. D. C. Bloomer, Life, 128-129, 172-173. There seem to be no records of the earnings of women lecturers prior to the Civil War but one assumes lecturing was profitable.

72. D. C. Bloomer, Life, 142; Dexter Bloomer, "Some Events." 
he looked on her departure with sincere regret. "For the past five years," Fuller wrote, "Mrs. Bloomer has managed the paper, both editorially and financially, displaying talents and business qualifications which but few of her friends were prepared to see her exhibit." 73

Bloomer continued to publish the Lily throughout 1854 from her home in Ohio. She wrote from one to three pages of original material for each issue and made the paper a bimonthly. In addition she published letters from correspondents and material from exchanges. Without Elizabeth Cady Stanton's contributions, however, the paper reverted to some of the blandness which had marked its early days. Bloomer also had the title of assistant editor for Dexter's Home Visitor, to which she contributed one or more articles each week. This work ended when Dexter sold his interest in the paper after only six months in Mt. Vernon. Printing the two periodicals in the same office had been problematic in at least one instance: in April Bloomer caused an uproar in Mt. Vernon when she hired a woman compositor for the Lily. The male printers for the Home Visitor refused to work with a woman and went out on strike. Amelia had wanted a woman printer for some time, but in Seneca Falls she had the Lily printed in the Courier office and thus had no control over hiring. Now she had her own type and was in a position to choose her own employee. During the heat of the strike Bloomer sent an urgent appeal for help to Lucy Stone, the pioneer feminist who was attending an antislavery convention in Cleveland. Stone responded by coming to Mt. Vernon to lecture on "Woman and Her Employments," which smoothed the troubled waters. The strike ended in late April when the employers hired four women and three men to work on both the Lily and the Home Visitor. ${ }^{74}$

Bloomer continued to give priority to the temperance cause although she remained a staunch supporter of woman's rights. She was a charter member of the Good Templars in Mt. Vernon and served as the presiding officer for the initiations of several prominent men into the mysteries of the lodge. She

73. D. C. Bloomer, Life, 142-148, 180-181.

74. D. C. Bloomer, Life, 154, 156, 175-179; Lily, 2 January, 15 April, 1 May 1854; Lucy Stone to Henry Blackwell, 23 April 1853, quoted in Elinor Rice Hays, Morning Star: A Biography of Lucy Stone (New York, 1961), 114. 
helped revive a Good Templars lodge in Alliance, Ohio which several men who had read about the Templars in the Lily had organized in March 1853. Bloomer also helped establish Good Templars chapters in other communities in Ohio and Indiana and she was in demand as a temperance lecturer. She attended the Ohio Woman's State Temperance Society convention in Columbus, where members elected her corresponding secretary. In June of 1853 she went to the second annual meeting of the New York Woman's State Temperance Society in Utica while en route to visit friends and relatives in the Seneca Falls area. She reported that the society was in even more prosperous condition than it had been at its meeting the previous year. ${ }^{75}$

Nevertheless, Bloomer was increasingly frustrated with politicians who only gave lip service to temperance. She encouraged the women of Mt. Vernon to take clubs in hand and break up the rum shops and gambling houses in the community. She told them that if men did not have the courage to boldly attack the foe, then women should take up the battle. She was also distressed that slavery was rapidly replacing temperance as the leading reform issue of the day. She deplored the absence of temperance candidates from the fall ticket of a "People's Convention" in Ohio. She believed that the temperance question was far more important than the Missouri Compromise or the Kansas-Nebraska bill. ${ }^{76}$

In the fall of 1854 Dexter Bloomer again went west looking for a new place to settle. This time he purchased a home site in Council Bluffs, Iowa, and the Bloomers decided to settle there the following spring. Council Bluffs was a frontier community with no facilities for printing and mailing the Lily to its many subscribers. Bloomer therefore felt forced to part with her paper. At the end of the year she sold it to Mary Birdsall of Richmond, Indiana, who published it for another two years. "We have deeply cherished The Lily," Bloomer wrote in her farewell editorial, but "home and husband being dearer to us

75. D. C. Bloomer, Life, 171-173, 184-186; Standard Encyclopedia of the Alcohol Problem, 1:2049.

76. D. C. Bloomer, Life, 160-161; Lorle Ann Porter, "Amelia Bloomer: An Early Iowa Feminist's Sojourn on the Way West," Annals of Iowa 45 (Fall 1979), 1255. 
than all beside, we cannot hesitate to sacrifice all for them; and so we cheerfully resign our pet to the care of its foster mother." After her arrival in Iowa, Bloomer still sent contributions to the Lily for several months. By October 1855, however, she reported that she was increasingly disinclined to write. Her new manner of life absorbed all of her attention. In January 1856 her name no longer appeared as corresponding editor of the Lily and the new editor published Bloomer's last letter from Council Bluffs on March 1, 1856. ${ }^{77}$

Although the Lily never measured up to the standard of radicalism which Elizabeth Cady Stanton would have liked, its more conservative stance kept it alive for several years. It brought the message to thousands of women that they were entitled to rights equal with men and it kept woman's rights advocates and temperance reformers in close touch. The Lily and the reform dress had made a name for Amelia Bloomer so that her reputation would precede her to Iowa. The Lily remained unique as the pioneer voice for the cause of women in the United States, and Amelia Bloomer carried its message herself to attentive audiences in the Midwest.

Editor's note: Part II of "Amelia Bloomer, A Biography," which elaborates Bloomer's life and moral reform activities in frontier Council Bluffs, and her efforts in Iowa on behalf of woman's suffrage, will appear in the next issue of the Annals of Iowa.

77. Dexter Bloomer, "Some Events"; D. C. Bloomer, Life, 188-189; Lily, October 1855. 
Copyright of Annals of Iowa is the property of State of Iowa, by \& through the State Historical Society of Iowa and its content may not be copied or emailed to multiple sites or posted to a listserv without the copyright holder's express written permission. However, users may print, download, or email articles for individual use. 